DOI: https://doi.org/10.24144/2409-6857.2019.1(53).229-232

УДК: 657. 1(043)

Загородній А. Г., Стрижка Т. А.

\title{
ВПЛИВ ОБЛІКОВОЇ ПОЛІТИКИ ПІДПРИЕМСТВА НА ВЕЛИЧИНУ СПЛАЧУВАНОГО ПОДАТКУ НА ПРИБУТОК
}

\begin{abstract}
У статті досліджено сутність облікової політики та процес ї̈ формування на підприємствах. Виявлено та проаналізовано проблеми пов'язані з вибором основних елементів облікової політики для мінімізації величини податкових платежів і запропоновано шляхи їх удосконалення. Визначено основні чинники впливу вибраних елементів облікової політики на величину сплачуваного податку на прибуток.
\end{abstract}

Ключові слова. Облікова політика, фінансовий результат, елементи облікової політики, податок на прибуток.

Постановка проблеми у загальному вигляді. В сучасних умовах економіки фінансовогосподарська діяльність підприємств потребує виваженого підходу до формування облікової політики. Вибір комплексу методичних прийомів, способів і процедур організації та ведення бухгалтерського обліку підприємством $є$ важливою складовою у процесі формування цієї політики. Ретельно продумана облікова політика забезпечує ефективну фінансово-господарську діяльність підприємства. Розробляючи принципи i методи формування облікової політики, підприємства повинні враховувати iї вплив на суми визнаних витрат або доходів та на фінансові результати.

Облікова політика підприємства істотно впливає на величини показників собівартості продукції та самого прибутку, податків на прибуток, додану вартість та на майно, а також на загальні показники фінансово-господарської діяльності.

Аналіз останніх досліджень і публікацій. Науковці приділяли суттєву увагу впливу облікової політики на бухгалтерський облік та фінансову звітність підприємства. Це питання досліджувалось у працях таких вчених, як Барановська Т. В., Голов С. Ф., Загородній А. Г., Ковальов В. В., Кужельного М. В., Лінник В. Г., Олійничук В. М., Оліховський В. Я., Партин Г. О., Пушкар М. С., Соколов Я. В. тощо.

За думкою Кужельного М. В. та Лінника В. Г. під обліковою політикою підприємства

(C) Загородній А. Г., к.е.н., проф. кафедри обліку та аналізу Національного університету «Львівська політехніка», м. Львів, (+38 032) 25823-21, zagorodniy@ polynet.lviv.ua

Стрижка T. А., магістр освітньо-наукової програми Національного університету «Львівська політехніка», м. Львів, +380986688156, tanjuschka24101995@gmail.com розуміють сукупність конкретних методів та способів організації та форм ведення бухгалтерського обліку, прийнятих підприємством на підставі загальних правил та особливостей його роботи [4].

$\mathrm{y}$ теоретичних та науково-практичних розробках Пушкар М. С. обгрунтовує необхідність та історичну зумовленість облікової політики, визначає фактори, що впливають на іiі формування, досліджує методологічну та організаційну сутність облікової політики $[12$, с. 18-24].

Оліховський В. Я. облікову політику розглядає як один із ефективних методів податкового планування, як важливий інструмент управління величиною податків, що сплачуються підприємством [6].

Партин Г.О. і Загородній А.Г. досліджуючи вплив облікової політики на результати фінансово-господарської діяльності, тобто визначають іiі як елемент фінансового менеджменту, а також пропонують розробляти іiі в двох аспектах - стосовно методики облікових робіт і стосовно їх організації [7].

Проте, питання впливу облікової політики на показники звітності залишаються недослідженими.

Формулювання цілей статті. Мета дослідження полягає у визначенні особливостей формування власної облікової політики підприємством та основних елементів її впливу на величину фінансових результатів.

Для досягнення поставленої мети вирішувались такі завдання:

- встановлення елементів облікової політики, які можуть впливати на витрати та фінансові результати підприємства;

- проведення аналізу впливу облікової політики на величину фінансових результатів та сплачуваного підприємством податку на прибуток; 
- обгрунтування шляхів удосконалення процесу формування облікової політики та вибору ii елементів 3 погляду зменшення податкового навантаження на підприємство.

Опис основного матеріалу дослідження. В сучасних економічних умовах фінансовий результат $\epsilon$ найважливішим показником ефективності роботи суб'єкта господарювання, основою його господарської діяльності та задоволення соціальних і матеріальних потреб працівників. Розмір фінансового результату залежить не тільки від виду діяльності, типу виробництва, підходів до організації збуту продукції, але й від обраної облікової політики та організації облікового процесу.

Відповідно до Закону України «Про бухгалтерський облік та фінансову звітність в Україні» облікова політика $\epsilon$ сукупністю принципів, методів та процедур, що використовуються підприємством для ведення бухгалтерського обліку, складання та подання фінансової звітності [3]. Застосування регулюючих впливів облікової політики зумовлює виникнення розбіжностей звітної та реальної величини фінансових результатів підприємства.

Нормативними документами щодо формування облікової політики $є$ Положення (стандарти) бухгалтерського обліку, якими передбачено порядок оцінки окремих об'єктів та альтернативні облікові методи. Перелік основних складових облікової політики підприємство визначає самостійно, проте основними іiі елементами мають бути ті, які впливають на величину фінансових результатів та стосуються обліку необоротних активів, запасів, дебіторської та кредиторської заборгованостей, витрат тощо.

Як видно 3 перелічених вище елементів, облікова політика підприємства $€$ важливим чинником, який впливає на результати його фінансово-господарської діяльності, оскільки вона може мати істотний вплив на основні показники собівартості продукції, прибутку, податків, показників фінансового стану. Облікова політика $є$ дієвим інструментом: управління витратами та фінансовими результатами, які впливають на показники фінансової звітності та фінансові коефіцієнти; уніфікації облікових процедур і зниження ї трудомісткості; управління нарахованими податками; практичного вирішення протиріч нормативних актів з бухгалтерського обліку та оподаткування; реалізації базових принципів обліку безперервності діяльності та методу нарахування.

На підставі аналізу наукових праць $[2,5,1]$, всі елементи облікової політики 3 урахуванням суттєвості впливу на фінансові результати та аналітичні показники фінансової звітності, рекомендуємо поділити на такі групи:

- елементи, що не здійснюють впливу на фінансові результати i аналітичні показники звітності: визначення одиниці аналітичного обліку запасів, спосіб складання звіту про рух грошових коштів, перелік створюваних забезпечень майбутніх витрат і платежів;

- елементи, за якими неможливо дати однозначну оцінку впливу: перелік і склад змінних і постійних загальновиробничих витрат, бази їхнього розподілу, перелік і склад статей калькулювання виробничої собівартості продукції (робіт та послуг);

- елементи з ймовірним впливом на аналітичні показники звітності і фінансові результати: підходи до переоцінки необоротних активів, метод амортизації основних засобів, нематеріальних активів, віднесення витрат, пов'язаних 3 поліпшенням об'єкта основних засобів, методи оцінки вибуття запасів, порядок обліку i розподілу транспортно-заготівельних витрат.

Саме останню з наведених груп елементів ми і будемо розглядати.

Методика обліку необоротних активів $\epsilon$ однією з важливих елементів облікової політики, яка здійснює вплив на величину фінансових результатів, зокрема, вибір методу нарахування амортизації. Використання прискорених методів амортизації виробничих основних засобів призводить до збільшення собівартості продукції та зменшення суми прибутку, а отже, й податку на прибуток. Прямолінійний метод же забезпечує при рівних обсягах виробництва рівну собівартість, а отже і порівнюваний фінансовий результат у різні періоди.

Значний вплив на оподатковуваний фінансовий результат діяльності підприємства здійснюе проведення переоцінки основних засобів до справедливої вартості. Дооцінка об'єктів основних засобів призводить до збільшення їх залишкової вартості і, відповідно, до збільшення амортизації, а уцінка навпаки - до зниження амортизації, зменшення витрат i збільшення прибутку.

Таким чином, фінансовий результат до оподаткування збільшується на суму уцінки основних засобів, включеної до витрат звітного періоду, та зменшується на суму дооцінки основних засобів. Об'єктами впливу цього елемента облікової політики є собівартість, інші витрати операційної діяльності, капітал у дооцінках, а отже, валюта балансу і вартість активів. 
Важливий вплив на фінансовий результат підприємства має також величина вартісного критерію належності матеріального активу до малоцінного необоротного активу, метод нарахування амортизації для малоцінних необоротних активів та термін корисного використання таких активів. П(С)БО 7 «Основні засоби» для таких активів передбачено два методи нарахування амортизації: списання на витрати $100 \%$ вартості при вводі об'єкта в експлуатацію і по 50 \% у місяцях вводу та вилучення активів 3 експлуатації. За першим методом у місяці введення цих об'єктів витрати будуть завищені, за другим - вартість малоцінних необоротних матеріальних активів відноситимуться на витрати більш рівномірно [10].

Методика обліку запасів передбачає вибір методу оцінки їхнього вибуття. Відповідно до П(С)БО 9 «Запаси» підприємства під час формування облікової політики, можуть обирати один 3 можливих способів визначення собівартості запасів: ідентифікованої собівартості відповідної одиниці запасів, собівартості перших за часом надходження запасів (ФІФО), середньозваженої собівартості, метод стандартних витрат, метод ціни продажу [11]. Від того, який метод списання виробничих запасів використовуватиметься залежить величина витрат, а отже і фінансових результатів.

Значний вплив на формування фінансових результатів має також вибір методу визначення резерву сумнівних боргів. П(С)БО 10 «Дебіторська заборгованість» передбачає три методи нарахування такого резерву: на підставі платоспроможності дебітора; на основі класифікації дебіторської заборгованості, на основі коефіцієнта сумнівності, який визначається шляхом розподілу фактичної суми втрат від списання безнадійної заборгованості за останні роки на загальну суму реалізації продукції (товарів, робіт, послуг) [9]. Кожен з цих методів по своєму впливає на величину витрат. При цьому необхідно відзначити, що застосування будь-якого 3 методів нарахування резерву сумнівних боргів $\epsilon$ чи не найсуб'єктивнішим моментом, адже жодних норм чи базових показників не існує.

Важливим також $є$ правильний вибір методу визнання доходів від реалізації продукції. Згідно п. 137.1 ст. 137 Податкового кодексу України дохід від реалізації товарів визнається за датою переходу покупцеві права власності на такий товар [8]. При чинному методі визнання доходів від реалізації продукції величина нарахованого прибутку не підкріплена реальним надходженням грошової маси на підприємство, оскільки цей метод ініціює відтік грошової маси за рахунок прискорення платежів до бюджету за податком на прибуток. Невелика затримка платежів покупцями може викликати погіршення фінансового стану підприємства. Тому такий метод стимулює підприємства до переходу на попередню оплату продукції, що не відповідає умовам нормальної ринкової економіки.

Одним із елементів облікової політики, який неявно впливає на фінансові результати є вибір порогу суттєвості. Суттєвою вважається та інформація, відсутність якої може вплинути на прийняття рішень сторонніми користувачами звітності. Від того, яке значення цього порогу буде обрано, залежить фінансовий результат, адже придбані активи, які не перевищують суттєвого значення, зразу ж будуть списані на витрати підприємства i, як наслідок, зменшать прибутковість підприємства.

Наведений перелік способів впливу облікової політики підприємства на величину фінансових результатів не $\epsilon$ вичерпним. Тому при формування облікової політики необхідно враховувати не тільки повноту, правильність та об'єктивність інформації щодо фінансових результатів за допомогою бухгалтерського обліку, але й уникнути необгрунтованого завищення або заниження показників фінансових результатів, визначених за правилами бухгалтерського обліку.

Висновки та перспективи подальших досліджень. Для досягнення оптимальної та ефективної облікової політики необхідно враховувати чинники, які мають вплив на іiі розробку. Формування облікової політики має бути орієнтоване на прийняття управлінських рішень щодо розподілу та ефективного використання наявних ресурсів i отримання фінансових результатів. Правильно розроблена облікова політика підприємства дає можливість вибирати ефективну схему для ведення бухгалтерського та податкового обліку, знижувати фінансові і податкові ризики, оптимізувати схему оподаткування, що в підсумку забезпечить належну ефективність, прийнятих економічних рішень і господарської діяльності підприємства.

Для того, щоб облікова політика стала не формальним атрибутом облікового механізму, а інформативною базою для прийняття управлінських рішень, необхідно: провести аналіз умов господарювання підприємства, його організаційної структури; проаналізувати фактичний стан бухгалтерського обліку та системи внутрішнього контролю; визначити мету та шляхи формування ефективної облікової політики. 
Таким чином, виходячи із суттєвого впливу облікової політики на фінансові результати діяльності підприємства, основою вибору іiі

елементів має бути стратегія підприсмства на найблину та в родальи перспективи.

\section{СПИСОК ВИКОРИСТАНИХ ДЖЕРЕЛ}

1.Будько О. Облікова політика як інструмент впливу на фінансові результати діяльності підприємства / О. Будько // Економічний аналіз. - 2010. - № 5. - С. 232 - 235.

2. Верига, Ю. А. Облікова політика підприємства : навч. посіб. / Ю. А. Верига, В. А. Кулик, Ю. О. Ночовна, С. Ю. Іванюк - Полтава: ПУЕТ «ЦУЛ», 2015. - 310 с.

3. Закон України «Про бухгалтерський облік та фінансову звітність в Україні» від 16 липня 1999 року № 996-XIV зі змінами та доповненнями.

4. Кужельний М. В., Лінник В. Г. Теорія бухгалтерського обліку : підручник / М. В. Кужельний, В. Г. Лінник K. : KHEУ, 2001. $-334 \mathrm{c}$.

5. Макарова Н. Н. Аналіз підходів до формування облікової політики / Н. Н. Макарова // Аудит и фінансовий аналіз. - 2009. - № 3 .

6. Оліховський В. Я. Вісник НУ ЛП № 722 «Менеджмент та підприємництво в Україні: етапи встановлення і проблеми розвитку». - Львів: Видавництво НУ ЛП 2012. - С. 177-181.

7. Партин Г.О., Загородній А.Г. Облікова політика та ії вплив на фінансові результати діяльності підприємства // Фінанси України. - 2001. - № 1. - С. 54-60.

8. Податковий кодекс України [Електронний ресурс]. - Режим доступу: http://zakon3.rada.gov.ua.

9. Положення (стандарт) бухгалтерського обліку 10 «Дебіторська заборгованість» : Наказ Міністерства фінансів України від 8.10.1999 р. № 237.

10. Положення (стандарт) бухгалтерського обліку 7 «Основні засоби» : Наказ Міністерства фінансів України від 27.04.2000 № 92.

11. Положення (стандарт) бухгалтерського обліку 9 «Запаси»: Наказ Міністерства фінансів України від 20.10 .1999 p. № 246.

12. Пушкар М.С. Облікова політика і звітність / М.С. Пушкар. - К. : Карт-бланш, 2004. - 141 с.

\section{REFERENCES}

1. Budko, O. (2010). Oblikova polityka yak instrument vplyvu na finansovi rezultaty diialnosti pidpryiemstva [Accounting policy as an instrument of influence on the financial results of an enterprise]. Ekonomichnyy analiz Economic analysis, 5, 232-235 [in Ukrainian].

2. Veriga, Yu. A. \& Kulik, V.A \& Nochevna, Yu. O. \& Ivanyuk S. Yu. (2015). Oblikova polityka pidpryiemstva [Accounting policy of фт enterprise]. Poltava: PUT «TSUL» [in Ukrainian].

3. Zakon Ukrainy «Pro bukhhalterskyi oblik ta finansovu zvitnist v Ukraini» [Law of Ukraine «On accounting and financial reporting in Ukraine»], № 996- XIV (1999, July 16). Kyiv: Parlam. vyd-vo [in Ukrainian].

4. Kuzhniy, M. V. \& Lynnyk V. G. (2001) Teoriia bukhhalterskoho obliku [Theory of accounting]. K.: KNEU [in Ukrainian].

5. Makarova, N. N. (2009) Analiz pidkhodiv do formuvannia oblikovoi polityky [Analysis of the approaches to the formation of accounting policy]. Audyt y finansovyy analiz - Audit and financial analysis, 3 [in Ukrainian].

6. Olikhovsky, V. Y. (2012) Menedzhment ta pidpryiemnytstvo v Ukraini: etapy vstanovlennia i problemy rozvytku [Management and entrepreneurship in Ukraine: stages of establishment and development problems]. Lviv: Vyd-vo NL [in Ukrainian].

7. Partin, G.O. \& Zagorodniy, A.G. (2001). Oblikova polityka ta yii vplyv na finansovi rezultaty diialnosti pidpryiemstva [Accounting policy and its impact on the financial results of an enterprise]. Finansy Ukrayiny - Finances of Ukraine, 1, 54-60 [in Ukrainian].

8. Podatkovyi kodeks Ukrainy [Tax Code of Ukraine] (n.d.). zakon.rada.gov.ua Retrieved from: http://zakon3.rada.gov.ua [in Ukrainian].

9. Polozhennia (standart) bukhhalterskoho obliku 10 «Debitorska zaborhovanist» [Regulation (standard) of accounting 10 «Accounts receivable»]: Order of the Ministry of Finance of Ukraine (1999, October 8) [in Ukrainian].

10. Polozhennia (standart) bukhhalterskoho obliku 7 «Osnovni zasoby» [Regulation (standard) of accounting 7 «Fixed assets»]: Order of the Ministry of Finance of Ukraine (2000, April 27) [in Ukrainian].

11. Polozhennia (standart) bukhhalterskoho obliku 9 «Zapasy» [Regulation (standard) of accounting 9 «Stocks»]: Order of the Ministry of Finance of Ukraine (1999, October 20) [in Ukrainian].

12. Pushkar, M. S. (2004). Oblikova polityka i zvitnist [Accounting policy and reporting]. K.: Kart-Blansh [in Ukrainian]. 